\title{
5 \\ Database for In-field Condition Assessments of Flood Control Infrastructure and Prioritization of Remedial Action Budgeting
}

\section{Peter Nimmrichter}

Since the passage of the Conservation Authorities Act in 1946, Authorities have been involved in assessing flood risk and implementing programs and projects related to providing flood protection to areas of existing development within their watersheds. Following Hurricane Hazel, in 1954, the Authorities adopted flood control as a core function and began to study and implement flood protection works in earnest.

The amalgamation of four existing Conservation Authorities into the Metropolitan Toronto and Region Conservation Authority (TRCA) in 1957 allowed for a more integrated approach to studying, prioritizing and funding such works across the region, as reflected in the TRCA 1959 Plan for Flood Control. Subsequent to the development of this plan, a multi-phased approach to providing flood protection began, including both structural and non-structural approaches to providing protection. It is the structural approaches that this study will deal specifically with, and include dams, weirs, drop structures, channels, and dykes. Many of these structures reflect the engineering approaches of the day, with the use of hardened surfaces such as concrete channels designed to convey flood waters in the most hydrologically efficient manner. Many of the original works constructed in

Nimmrichter, P. 2008. "Database for In-field Condition Assessments of Flood Control Infrastructure and Prioritization of Remedial Action Budgeting." Journal of Water Management Modeling R228-05. doi: 10.14796/JWMM.R228-05.

(C) CHI 2008 www.chijournal.org ISSN: 2292-6062 (Formerly in Reliable Modeling of Urban Water Systems. ISBN: 978-0-9808853-0-9) 
the late 1950 s and early 1960 s are reaching their structural life expectancy. Developing an efficient monitoring, reporting and assessment system is critical to determining the liability that these existing facilities present.

\subsection{Objectives}

The fundamental theme of this project was the creation of a database application to support the management of TRCA flood protection infrastructure and provide some standard, basic queries and reports regarding the identification and prioritization of remedial maintenance requirements on an annual basis. The primary project objectives are as follows:

development of inspection criteria and procedures to be used to assess the existing flood protection infrastructure including the creation of automated field inspection forms compatible with digital hand held devices, which allow for the collection of data relating to TRCA flood protection works in keeping with the Authority's needs;

development of criteria and protocols to be used to ascertain the need and priority for works related to providing general maintenance, minor or preventative maintenance related to failure and major maintenance related to failure;

development of a spatial/relational monitoring, assessment and reporting database tool that will permit TRCA to easily collect field inspection and other data, analyze the data and identify and prioritize remedial maintenance requirements on an annual basis;

population of the application database with the results of a cursory field inspection of the flood protection infrastructure, including a preliminary risk assessment and integration of information collected in the field into the new database tool; and

- development of prioritization reports for the existing infrastructure based upon the results of the cursory field inspection. 


\subsection{Study Area}

The study area encompasses the entire TRCA jurisdiction and includes a variety of flood protection infrastructure currently owned and managed by TRCA. Table 5.1 identifies the 32 sites, and range of infrastructure, that were identified by TRCA to be included within the scope of this project.

It must be noted that, in the context of this study/application development effort, inspections, as required by the terms of reference, were "cursory visual inspections" only. Inspections completed for this study should not be equated with more rigorous dam safety inspections, although information similar to that collected during a dam safety inspection was obtained.

Cursory field inspections were completed in Spring 2006.

\subsection{Maintenance Prioritization System}

\subsubsection{Overview}

The primary objective of this application is the management of Maintenance Prioritization through the provision of user functionality to support the collection of flood control infrastructure inspection data, the analysis and interpretation of inspection results, and the prioritization of maintenance procedures. The information generated using the Maintenance Prioritization tool will subsequently be used to support the generation of a work program with associated budgeting, leading to site remediation. The remediation results are captured in the next site inspection.

The Maintenance Prioritization System comprises five modules, namely:

\footnotetext{
Site Details This module supports the maintenance of flood control site information.

Inspections This module supports the collection of observations on the condition of infrastructure at a flood control site. It also supports the ability to assess the condition of each structure with respect to evaluation criteria, to propose remedial work for a site, if required, and to classify the work in terms of importance to complete.

Field Data This module supports the download and upload of flood control site data to and from field data collection units.
} 
Analysis This module supports the prioritization of flood control sites for remedial action based upon field inspection data. This prioritization is used as input into a budgeting process.

Administration This module supports administrative functions such as creating sites, retiring sites, modifying prioritization data.

Table 5.1 Flood control infrastructure sites to be inspected.

\begin{tabular}{|c|c|c|}
\hline Site \# & Site Name & Description \\
\hline 1001 & Long Branch & Steel Sheet Piling Revetment \\
\hline 1002 & Berry Road & Gabion Protection \\
\hline 1003 & Lower Humber Channel & Concrete Weirs \\
\hline 1004 & Scarlett Road Channel & Concrete Channel \\
\hline 1005 & Claireville Dam & Concrete and Earth Fill \\
\hline 1006 & Emery Creek Channel & Gabion Channel \\
\hline 1007 & Black Creek Retardation Dam & Concrete Earth Filled Dam \\
\hline 1008 & Massey Creek Channel & Weirs \\
\hline 1009 & York Mills Channel & Concrete and Gabion Channel \\
\hline 1010 & West Don at Sheppard & Concrete Channel \\
\hline \multirow{3}{*}{1011} & YMHA & Baffle Chute \\
\hline & & Gabion lined channel \\
\hline & & Dragon tooth energy dissipater \\
\hline 1012 & G Lord Ross Dam & Concrete and Earth Fill \\
\hline 1013 & Malvern Channel & $\begin{array}{l}\text { Gabion drop structures \& erosion protection } \\
\text { Concrete chute }\end{array}$ \\
\hline 1014 & Metro Zoo Channels & $\begin{array}{l}\text { Grass and rip rap lined channel } \\
\text { Baffle chute }\end{array}$ \\
\hline 1015 & Dixie/Dundas Channel & Armor Stone Channel \\
\hline 1016 & Etobicoke Creek Levee & Flood Control Levee \\
\hline 1017 & Brampton Diversion Channel & Concrete Channel \\
\hline 1018 & Mimico-Malton Channel & Gabion Basket Channel \\
\hline 1019 & Woodbridge Channel & $\begin{array}{l}\text { Rip-Rap Channel } \\
\text { Concrete Dragons Tooth Weirs }\end{array}$ \\
\hline 1020 & Bolton Channel and Dyke & $\begin{array}{l}\text { Rip-Rap and earthen by-pass channel, } \\
\text { Levee }\end{array}$ \\
\hline 1021 & Albion Hills Dam & Earth Fill Dam \\
\hline 1022 & Palgrave Dam & Concrete Dam \\
\hline 1023 & Glen Haffy Dam & Two (2) earth fill dams \\
\hline 1024 & Milne Dam & Concrete and Earth Filled Dam \\
\hline 1025 & Markham School Channel & Gabion lined channel \\
\hline 1027 & $\begin{array}{l}\text { Pickering/ } \\
\text { Ajax Flood Control Dyke }\end{array}$ & Earth fill levee \\
\hline 1028 & Stouffville Dam & Concrete Earth Filled Dam \\
\hline 1029 & Stouffville Channel & Gabion Channel \\
\hline 1030 & Tyndall Nursing Home & Concrete and masonry flood wall \\
\hline 1031 & Osler Dam & Earth and concrete dam \\
\hline 1032 & Secord Dam & Earth and concrete dam \\
\hline 1033 & The Brick on Dundas Dyke & Earthen Levee \\
\hline
\end{tabular}


Each of the modules noted above is accessed from the main system menu (see Figure 5.1).

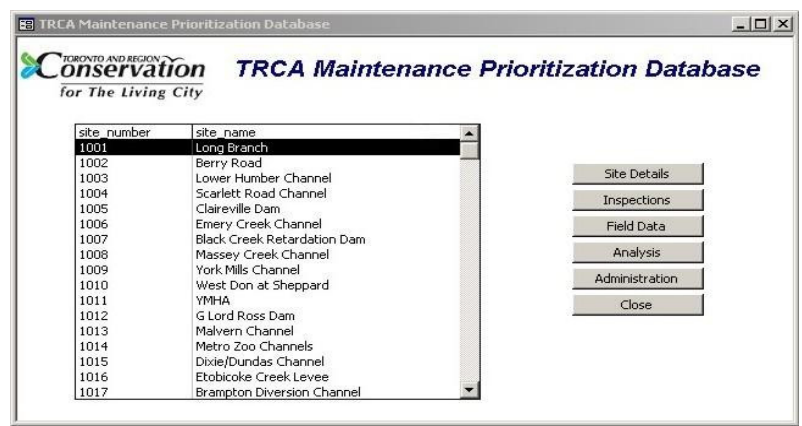

Figure 5.1 Main menu.

\subsubsection{Defining a Site}

In the context of this application, a Site is a location where flood control infrastructure exists. The Malvern Channel, Milne Dam and Long Branch are examples of Sites. From a GIS perspective, a site can be a point or linear feature. In the case of Long Branch, the dot on the map defines the Site location. As noted previously, the present database contains definitions for 32 sites.

As some Sites span significant

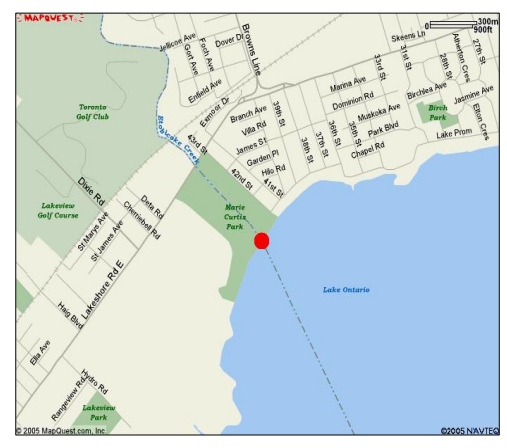
watercourse reaches or are complex in their makeup, Sites are broken down into manageable pieces referred to as Sub-Sites. A typical means of defining Sub-Sites is by spatial location or extent within the Site or by structure type. Using Long Branch as an example, the site is made up of sheet piling revetment on both banks and erosion protection for a short distance upstream of the sheeting piling, also on both banks. In this case, the sub-sites defined for Long Branch were Reach \#1 - from the outlet to Lake Ontario to the upstream limit of the sheet piling (see Photo 1) and Reach \#2 - from the 
upstream limit of the sheet piling to the upstream limit of the erosion protection works (see Photo 2).

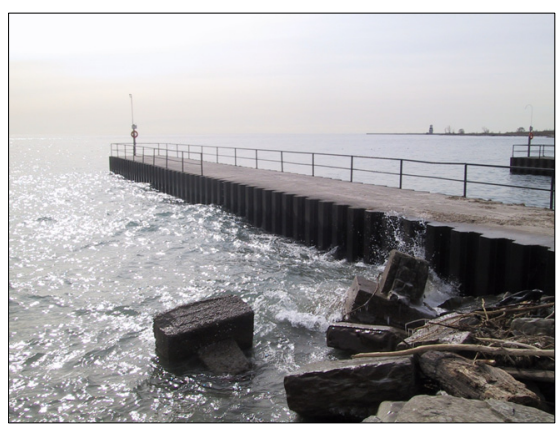

Photo 1

Site: Long Branch

Sub-Site: Reach \#1

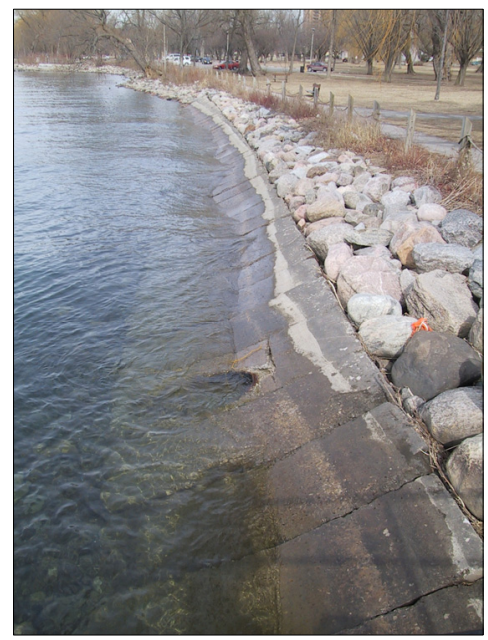

Using this approach, the 32 flood control sites in the database were broken down into 79 sub-sites.

The definition of sub-sites also includes data that defines hazard potential or risk associated with that sub-site. Risk, in the context of this application, is used to define a hazard classification for an element of flood control infrastructure in a manner similar to that outlined in the Lakes \& Rivers Improvement Act Technical Guidelines - Criteria and Standards for Approval (MNR, 2004) for dams.

Dams are classified according to the potential impact of dam failure or mis-operation that it would have on life, property, and the environment at the site, upstream, downstream, or at other areas remote from the dam. The hazard potential related to possible loss of life or property damage (social and economic) is based on both present land use and on future development potential within 20 years. There are four hazard potential classification (HPC) levels based on the order of increasing adverse incremental consequences as described below (taken from MNR, 2004). Criteria for determining the HPC of dams are described in Table 5.2. 
Table 5. 2 Hazard potential classification criteria for regulated dams (MNR 2004)

\begin{tabular}{|c|c|c|c|}
\hline $\begin{array}{l}\text { Hazard } \\
\text { Potential }\end{array}$ & $\begin{array}{l}\text { Potential for } \\
\text { Loss of Life }\end{array}$ & Economic and Social Losses & Environmental Losses \\
\hline \multirow[t]{2}{*}{ Very Low } & \multirow[t]{2}{*}{ None } & Damage to dam only; little to other property & Short term: Minimal \\
\hline & & Estimated losses do not exceed $\$ 100,000$ & Long term: None \\
\hline \multirow[t]{2}{*}{ Low } & \multirow[t]{2}{*}{ None } & $\begin{array}{l}\text { Minimal damage to agriculture, other dams, } \\
\text { or structures not for human habitation. The } \\
\text { inundation area that could be flooded, if the } \\
\text { dam fails, is typically undeveloped. No } \\
\text { damage to residential, commercial, indust- } \\
\text { rial, or land to be developed within } 20 \text { y }\end{array}$ & \multirow{2}{*}{$\begin{array}{l}\text { No significant loss/ deterior- } \\
\text { ation of fish and/or wildlife } \\
\text { habitat. Loss of marginal } \\
\text { habitat only. Feasibility } \\
\text { and/or practicality of } \\
\text { restoration or compensation } \\
\text { in kind is high and/or good } \\
\text { capability of channel to } \\
\text { maintain or restore itself. }\end{array}$} \\
\hline & & Estimated losses do not exceed $\$ 1$ million. & \\
\hline \multirow[t]{2}{*}{ Significant } & \multirow[t]{2}{*}{$\begin{array}{l}\text { None } \\
\text { Expected }\end{array}$} & $\begin{array}{l}\text { Appreciable damage to agricultural } \\
\text { operations, other dams or residential, } \\
\text { commercial, industrial development, or land } \\
\text { to be developed within } 20 \mathrm{y}\end{array}$ & \multirow{2}{*}{$\begin{array}{l}\text { Loss or significant } \\
\text { deterioration of important } \\
\text { fish and/or wildlife habitat. } \\
\text { Feasibility and/or practicality } \\
\text { of restoration and/or } \\
\text { compensation in kind is high } \\
\text { and/or good capability of } \\
\text { channel to maintain or } \\
\text { restore itself. }\end{array}$} \\
\hline & & $\begin{array}{l}\text { Development within inundation area is } \\
\text { predominantly rural or agricultural, or it is } \\
\text { managed so that the land usage is for transi- } \\
\text { ent activities such as with day-use facilities. } \\
\text { Estimated losses do not exceed } \$ 10 \text { million. }\end{array}$ & \\
\hline High & 1 or more & $\begin{array}{l}\text { Extensive damage to communities, } \\
\text { agricultural operations, and infrastructure. } \\
\text { Typically includes destruction of or } \\
\text { extensive damage to large residential areas, } \\
\text { concentrated commercial and industrial } \\
\text { land uses, highways, railways, power lines, } \\
\text { pipelines, and other utilities. } \\
\text { Estimated losses exceed } \$ 10 \text { million. }\end{array}$ & $\begin{array}{l}\text { Loss or significant deter- } \\
\text { ioration of critical fish and/or } \\
\text { wildlife habitat. Feasibility } \\
\text { and/or practicality of } \\
\text { restoration and/or compens- } \\
\text { ation in kind are low and/or } \\
\text { poor capability of channel to } \\
\text { maintain or restore itself. }\end{array}$ \\
\hline \multirow{2}{*}{\multicolumn{4}{|c|}{$\begin{array}{l}\text { 1. Losses refer to incremental losses resulting from dam failure, appurtenant facilities, or mis-operation of } \\
\text { dam. } \\
\text { 2. Consideration must be given to the cascade effect of dam failures. If failure of an upstream dam could } \\
\text { contribute to failure of downstream dams, the minimum HPC of the upstream dam should be the same as } \\
\text { or greater than the highest downstream HPC of the downstream dam(s). }\end{array}$}} \\
\hline & & & \\
\hline \multicolumn{4}{|c|}{$\begin{array}{l}\text { 3. Economic losses refer to all direct losses to third parties; they do not include losses to owner, such as, } \\
\text { loss of the dam, associated facilities and appurtenances, loss of revenue, etc. }\end{array}$} \\
\hline \multicolumn{4}{|c|}{$\begin{array}{l}\text { 4. The HPC assigned to a dam should be based on the worst-case scenario (i.e., failure condition that will } \\
\text { result in the greatest potential for loss of life, property damage, and/or environmental impact). }\end{array}$} \\
\hline \multicolumn{4}{|c|}{$\begin{array}{l}\text { 5. Social economic losses to take into consideration planned development outlined in official planning } \\
\text { documents (projected } 20 \text { year horizons). }\end{array}$} \\
\hline \multicolumn{4}{|c|}{$\begin{array}{l}\text { 6. The HPC does not reflect the current condition of the dam. } \\
\text { 7. Flooding and/or erosion rights may also be acquired downstream to reduce the possibility of raising the } \\
\text { HPC in the future and/or increasing the IDF. }\end{array}$} \\
\hline
\end{tabular}


Very Low Hazard Potential: Dams in this classification are those where adverse incremental consequences of failure or mis-operation of the dam would be minor and limited to the dam structure and confined to the immediate vicinity, principally within the limits of the property belonging to the dam owner. There is no expected loss of life, no incremental damage to property (other than the dam itself). Adverse consequences on the environment would be minimal in the short term and none in the long term.

Low Hazard Potential: Dams in this classification are those where adverse incremental consequences of failure or mis-operation of the dam would be low and primarily limited to the property belonging to the dam owner. There is no expected loss of life and any adverse social and economic impacts on other property are low. There would be no significant loss or deterioration of fish and/or wildlife habitat and only a probable loss of marginal habitat. Feasibility and/or practicality of restoration or compensation in kind must be high and/or good capability of channel to maintain or restore itself.

Significant Hazard Potential: Dams in this classification are those where adverse incremental consequences of failure or mis-operation of the dam would be significant, but there is no expected loss of life. Damage to property and the environment would be significant and will extend beyond the property of the dam owner. There may be loss or significant deterioration of important fish and/or wildlife habitat. Feasibility and/or practicality of restoration and/or compensation in kind would be high and/or good capability of channel to maintain or restore itself.

High Hazard Potential: Dams in this classification are those where adverse incremental consequences of failure or mis-operation of the dam would result in probable loss of life; damage to property and the environment would be extensive, extending beyond the property of the dam owner and affecting communities. There may be loss or significant deterioration of critical fish and/or wildlife habitat. Feasibility and/or practicality of restoration and/or compensation in kind would be low and/or poor capability of channel to maintain or restore itself.

In the context of the evaluation of hazard potential the term incremental describes the difference in impacts that would occur due to failure or misoperation of the dam over those that would have occurred without failure or mis-operation of the dam and appurtenances. In other words, if downstream flood levels associated with a Regulatory Flood were the same with or 
without an upstream dam failure the incremental impacts resulting from that failure would be zero.

To assist the reader in better understanding the hazard classification system adopted for the TRCA Maintenance Prioritization System, two relevant reference documents are suggested:

- Section 5 of the Lakes \& Rivers Improvement Act Technical Guidelines - Criteria and Standards for Approval (MNR, 2004)

- Instruction Memorandum No. RS-99-005, Revised Criteria for Assigning Hazard Potential Ratings to Bureau of Land Management Dams (USBR, 1998)

The same four risk classes are defined in the Maintenance Prioritization System, namely; Very Low, Low, Significant and High. From the system perspective, these risk classes are defined numerically in the ranges outlined in Table 5.3. The use of a range provides the opportunity to recognize increasing or decreasing risk within a Site.

Table 5.3 Maintenance prioritization system risk classes.

\begin{tabular}{ccc}
\hline Class & Numeric Range & Risk Type \\
\hline Very Low & 100 to 199 & 1 \\
Low & 200 to 299 & 2 \\
Significant & 300 to 399 & 3 \\
High & 400 and greater & 4 \\
\hline
\end{tabular}

The selection of the risk type for sub-sites, presently defined in the database, was made on a presumptive basis from review of surrounding land uses and infrastructure, site reconnaissance and potential consequences of flood control infrastructure failure for the majority of sites. For a limited number of dam sites, dam safety reviews have been completed and, where available, sub-site risk type was defined from the dam safety review.

An element of a dam safety review is the establishment of the inflow design flood (IDF). The IDF is also linked to the hazard potential for a dam structure and can range from a $100 \mathrm{y}$ event to the probable maximum flood (PMF). To assist with the qualitative assessment of potential failure impacts towards defining the preliminary sub-site risk types for the TRCA Maintenance Prioritization System, the Regulatory Flood was used.

A sub-site's risk type, when it is not obvious from the visual evidence, may be confirmed through a detailed incremental hazard evaluation. This evaluation would consider the incremental flood depths and velocities resulting from failure of flood control infrastructure on downstream property 
and land use. Expected damages and loss of life would be determined based on both depth and velocity resulting from detailed hydraulic studies.

Further, the risk type associated with a sub-site may change over time. Downstream development, alterations to the sub-site, the finding of an endangered or threatened species (plant or animal), or revisions to hydrology or hydraulic characteristics of the watershed could warrant changing the risk type. Thus it is important to review the risk type on a periodic basis.

Two examples of the use of the risk range are the Scarlett Road Channel and the YHMA site. At these sites risk values on the upstream sub-sites of the channel are defined higher than those in the downstream zone to take into account the potential for a cascade failure starting at the upstream end of the site. In the case of the Scarlett Road Channel site a uniform increase in risk value was assigned as indicated below. In the case of the YHMA site, a uniform increase was assigned to sub-sites of a similar type (i.e. channel) and an increased risk value assigned at the extreme upstream limit of the site where the assigned risk type changed.

$\begin{array}{llll}\text { Site \# } & \text { Sub-Site Description } & \text { Risk } & \begin{array}{c}\text { Risk } \\ \text { Value }\end{array} \\ \text { Scarlett } & \text { Road Channel } & \text { Type } & \\ 1004 & \begin{array}{l}\text { Reach \#1 - Channel Section \#1 (thru Lambton Golf and Country } \\ \text { Club) }\end{array} & 2 & 200 \\ 1004 & \text { Reach \#2 - Channel Section \#2 (Scarlett Rd to Jane St) } & 2 & 205 \\ 1004 & \text { Reach \#3 - Channel Section \#3 (Jane St to Castleton Ave) } & 2 & 210 \\ 1004 & \text { Reach \#4 - Channel Section \#3 (Castleton Ave to Alliance Ave) } & 2 & 215 \\ 1004 & \text { Reach \#5 - Channel Section \#3 (Alliance Ave to Weston Rd) } & 2 & 220 \\ \text { YHMA Site } & 3 & 300 \\ 1011 & \begin{array}{l}\text { Reach \#1 - Bathurst St (D/S limit of site) to first footbridge } \\ 1011\end{array} \quad \begin{array}{l}\text { Reach \#2 - first footbridge to roadway crossing to parking lot } \\ 1011\end{array} \quad \begin{array}{l}\text { Reach \#3 - roadway crossing to parking lot to next U/S foot } \\ \text { bridge }\end{array} & 3 & 305 \\ 1011 & \text { Reach \#4 - next U/S foot bridge to Baffle Chute } & 3 & 310 \\ 1011 & \text { at Baffle Chute }\end{array}$

The next step in defining a site is to break down the sub-sites into their component elements. Components are the flood control infrastructure elements that make up a sub-site. Table 5.4 provides a listing of all of the components types presently defined in the Maintenance Prioritization system. 
Table 5. 4 Maintenance prioritization system - component definitions.

\begin{tabular}{ll}
\hline Access Road & Outlet Erosion Control \\
Channel Bottom & Reservoir \\
Channel Bank & Safety Issues - Channel \\
Embankment - Crest & Safety Issues - General \\
Embankment - Downstream Slope & Seepage \\
Embankment - Upstream Slope & Sheet Piling \\
Erosion Protection & Spillway - General \\
Flood Wall - General & Spillway - Downstream Side \\
Flood Wall - Crest & Spillway - Inlet Channel Bottom \\
Flood Wall - Dry Side & Spillway - Inlet Channel Bank \\
Flood Wall - Wet Side & Spillway - Outlet Channel Bottom \\
Levee - General & Spillway - Outlet Channel Bank \\
Levee - Embankment Crest & Spillway - Upstream Side \\
Levee - Embankment - Dry Side & Weir \\
Levee - Embankment - Water Side & \\
Low Level Outlet - General & \\
Low Level Outlet - Channel Bank & \\
Low Level Outlet - Channel Bottom & \\
\hline
\end{tabular}

Using these components as building blocks, the infrastructure making up a sub-site is "constructed". Again, using Long Branch as an example, the following components were used for each of the sub-sites.

\begin{tabular}{ll}
\multicolumn{1}{c}{ Reach \#1 } & \multicolumn{1}{c}{ Reach \#2 } \\
Sheet Piling - Right Bank & Erosion Protection - Right Bank \\
Sheet Piling - Left Bank & Erosion Protection - Left Bank \\
Safety Issues - General - Right Bank & Channel Bottom \\
Safety Issues - General - Left Bank & \\
Channel Bottom &
\end{tabular}

Using this method, the 79 sub-sites in the database were defined using 482 components.

The Maintenance Prioritization System provides functionality to define all aspects of a Site, its Sub-Sites and associated Components.

\subsubsection{Inspections}

The Inspection module supports the field inspection of flood control infrastructure. Several field trips will typically be required to assess all TRCA flood control sites, but several sites can be inspected in one field inspection outing. As shown in Figure 5.2, the work flow for an Inspection 
begins with downloading the data from the master Maintenance Prioritization System to the field inspection hardware. Once in the field, the user will launch the Maintenance Prioritization application and select the Inspection module. The user will then select the site to be inspected. The user will then select the sub site and component to be inspected. The user will capture field observations using checklist forms available on the field inspection hardware. The component inspection is repeated until all components for the site have been assessed. Once the site is completely assessed, the user will move to the next site until all site inspections in the current inspection plan have been completed. Upon return to the TRCA offices, the field data will be uploaded to the Maintenance Prioritization System.

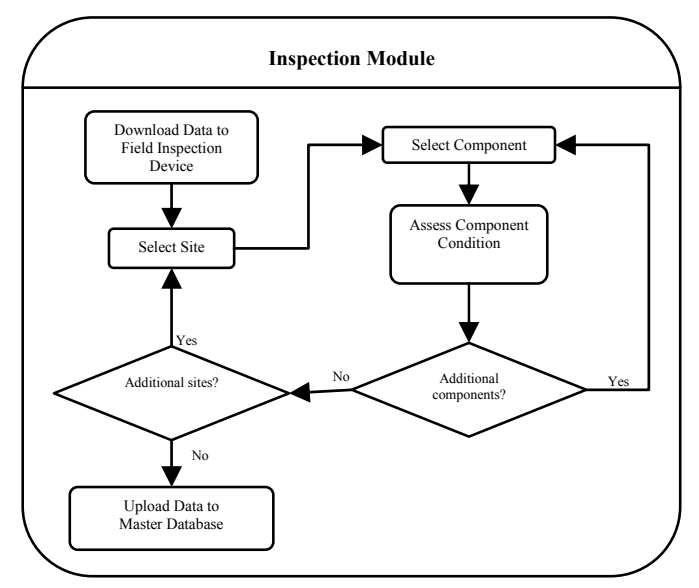

Figure 5.2 Inspection Module Work Flow.

The Inspections subsystem provides a site specific view of inspections undertaken for the site highlighted on the Main Menu. Two Inspection form views are available to the user and which the user sees is dependent on the status of the default inspection (i.e., the first inspection record) available for the site). The System presently defines four status levels for inspections, namely:

Field Collection Inspections have this status when first defined and while residing in the field database. The inspector has access to all appropriate checklists with this status. 
Office Review Inspections have this status upon upload from the field database to the office / central database. This interim status provides an opportunity for the field inspector to review photos, other available data, collaborate with colleagues to finalize the observations collected in the field. The inspector has access to all appropriate checklists with this status.

Reviewed At the point when the field observations are considered final the inspection status can be changed to Reviewed. No changes to the inspection observations are permitted with this status.

However, additional functionality becomes available to the user under this status to define remedial actions at a site.

Complete Once the user has defined remedial actions applicable at a site the status can be changed by the user to Complete.

Once an inspection has been flagged as Complete, the results of the inspection can be included in a Prioritization Analysis.

In-field data capture is completed via a series of checklists, each specific to the type of infrastructure (as noted in Table 5.4) under inspection. Component checklists provide the primary means of collecting field observations. An example of a Weir inspection checklist is illustrated in Figures 5.3a and 5.3b. Checklists are tabbed forms made up of dropdown and list boxes providing pre-defined selections for key component elements that the inspector should observe in the field.

The General tab is generic to all checklists and allows the inspector to confirm that the component was inspected. If not, an area is provided for a description of why an inspection was not completed. The Available Checklists area of the General tab provides the inspector with the list components elements to observe during the inspection.

To access the Available Checklists, the inspector must confirm that the inspection was completed by checking the "Was inspection completed?" box. This acknowledgement provides the inspector with access to the Available Checklists which are specific to each component. 
Each available checklist represents a tab of information to be gathered in the field. Access to these checklists is provided upon checking which tabs are required (typically all). It is not necessary to complete all of the tabs, however it is recommended.

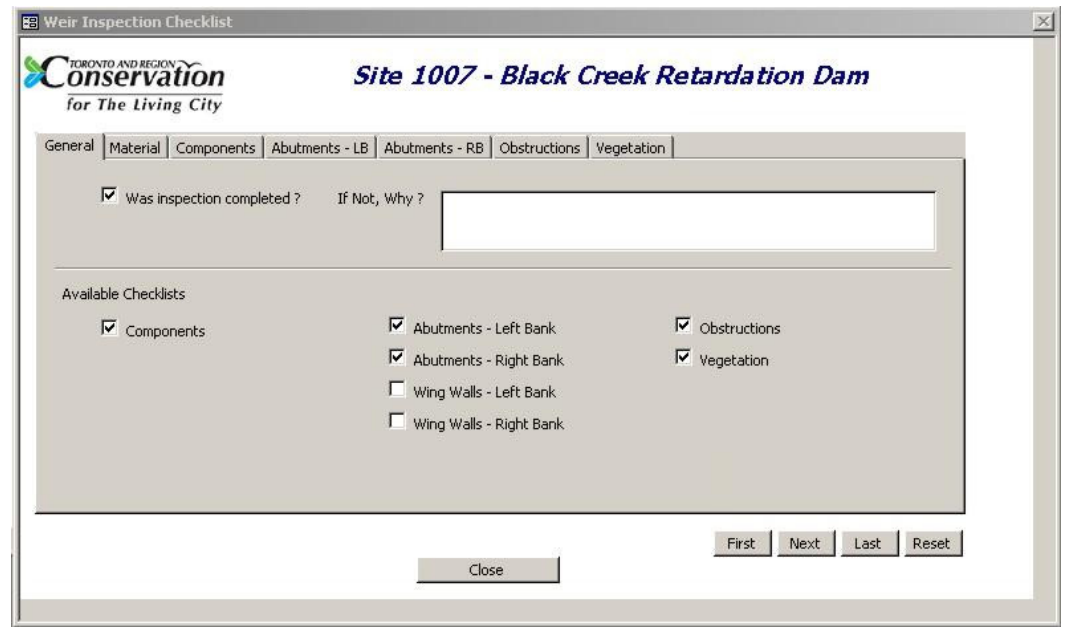

Figure 5.3a Weir Inspection Checklist - General Tab.

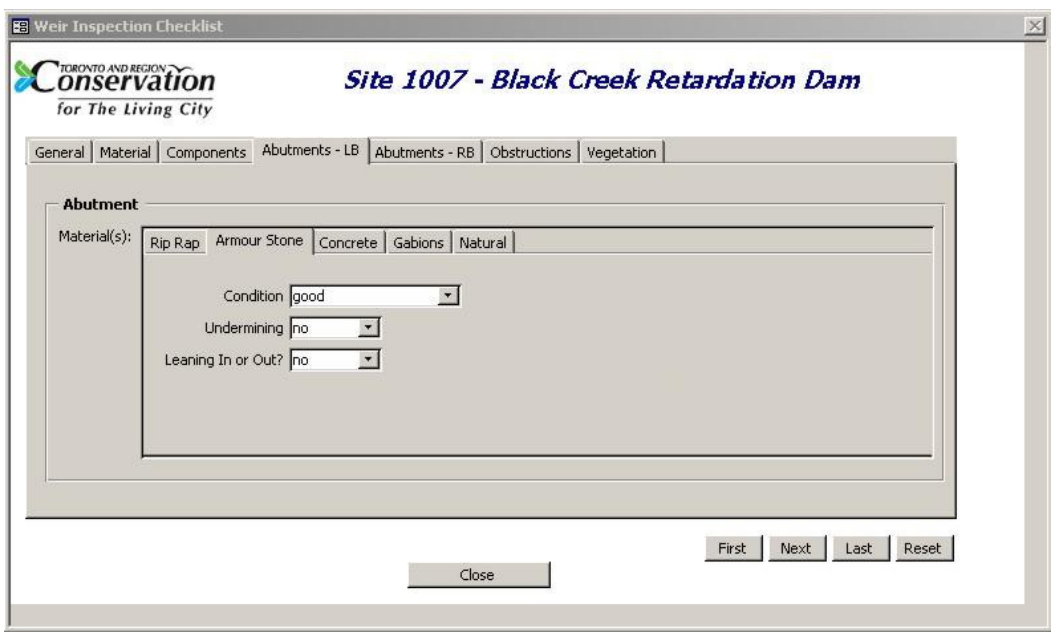

Figure 5. 3b Weir Inspection Checklist - Abutments Tab. 
Checklist items are defined with Inspection Item Factors which define the potential severity of the observation. For example, no bulges on the downstream slope of an abutment would have an Inspection Item Factor of 0 ; a noticeable bulge would have an Inspection Item Factor of 10; and many noticeable bulges would have an Inspection Item Factor of 20. These Inspection Item Factors support the Prioritization Analysis.

\subsubsection{Remedial Actions}

If a checklist item, whose Inspection Item Factor is greater than zero, is selected to describe a field observation, the system will flag the requirement for definition of a remedial action. In other words, the inspector made a field observation that suggests some remedial action is required to correct a component at the site. The Remedial Actions sub-system provides the user with the list of inspection observations that suggest the requirement for a remedial action and the functionality to define those remedial actions.

The system presently defines four remedial actions, namely; Monitoring (the default), Analysis, Capital Works and Emergency Works. Each of these possible remedial actions also has an associated Remedial Action Factor which is used in the Prioritization Analysis. The Remedial Action Factors presently defined in the system are $25,50,100,1000$, respectively for the actions noted above. These factors reflect the urgency associated with correcting the issue observed in the field.

\subsubsection{Prioritization Analysis}

The Analysis module supports the functionality to enable TRCA to assess the condition of the flood control infrastructure, to identify structure components that require some degree of maintenance, to rank and prioritize actions across all flood control infrastructure sites, and to contribute to the budgeting process to conduct remediation activities.

The Prioritization Summary Report ranks sites based on a combination of risks associated with sites/subsites, observation collections during the cursory field inspections and user defined remedial actions. The algorithm used to evaluate the ranking is as follows:

Sum Total of [Remedial Action Factor x Sub Site Risk Factor x Inspection Item Factor]

[Number of Defined Remedial Actions for the Site] 
The result is a priority ranking identifying cumulative potential issues requiring attention at individual sites.

\section{References}

AMEC (2005). TRCA Maintenance Prioritization Database, Solution Requirements Specification, AMEC, November 2005

MNR (2004). Lakes and Rivers Improvement Act Technical Guidelines - Criteria and Standards for Approval [draft].

USBLM (1998). Revised Criteria for Assigning Hazard Potential Ratings to BLM Dams, United States Department of the Interior, Bureau of Land Management, National Applied Resource Sciences Center, Denver, Colorado 80225-0047, October 21, 1998. 